\title{
Sensitivity of the snowcover energetics in a mountain basin to variations in climate
}

\author{
Michele L. Reba, ${ }^{1 *}$ Danny Marks,${ }^{1}$ Adam Winstral, ${ }^{1}$ Timothy E. Link ${ }^{2}$ and Mukesh Kumar ${ }^{3}$ \\ ${ }^{1}$ Agricultural Research Service, Northwest Watershed Research Center, Boise, ID 83712, USA \\ ${ }^{2}$ College of Natural Resources, University of Idaho, Moscow, ID 83844, USA \\ ${ }^{3}$ Nicholas School of Environment, Duke University, Durham, NC 27708, USA
}

\begin{abstract}
:
Snow is an important natural reservoir that holds water on the landscape for release later in the season in western North America and other portions of the world. As air temperature increases with global climate change, the character of the generally established seasonal snowcover will be affected. To study the specific response to variable climate, a carefully collected and processed meteorological data set for the 1984-2008 water years (WYs) was assembled for a snow-dominated headwater mountain catchment. The data were used to force a physically based, distributed energy balance snow model to simulate patterns of snow deposition and melt over the catchment for the 25 -year period. This period covers both the highest (1984) and lowest (1992) snow seasons on record and exhibits extreme inter-annual variability. This unique forcing data set captured meteorological conditions that resulted in the range of variability in snowcover accumulation, timing of ablation, and the timing and amount of surface water input (SWI), and discharge during the 25 -year study period. SWI is the amount of liquid water delivered to the soil surface from melting snow or from rain that passes through the snowcover or falls directly on the soil. Warm winters, characterized by early- and mid-winter rain, triggered earlier inputs from SWI and response in discharge than cool winters. Cool conditions prolonged the generation of SWI and streamflow out of the basin. Very wet conditions that were warm passed 50\% of the SWI 27 days earlier and passed 50\% of the discharge 15 days earlier, when compared to very wet conditions that were cool. Warmer conditions produced less snow water equivalent, shortened the melt season, and would be expected to extend the summer drought. Copyright (c) 2011 John Wiley \& Sons, Ltd.
\end{abstract}

KEY WORDS snowmelt; energy balance model; climate change

Received 14 September 2010; Accepted 4 April 2011

\section{INTRODUCTION}

Snow is a major component of the annual water balance in many locations throughout the world. In the interior western USA, where water supplies are scarce and overallocated, snowfall accounts for $50-80 \%$ of total precipitation (Hanson, 2001). To maximize efficiency and limit flood risk, accurate runoff forecasts are required. Management strategies based on historic relationships between snow deposition patterns from index sites and stream discharge may become unstable under a modified climate, which will greatly impact water resources management.

General findings in climate change research agree that temperatures are increasing (IPCC, 2007; Trenberth et al., 2007). Specifically, findings in western North America have shown climate warming impacts snow deposition and melt (Cayan et al., 2001; McCabe and Clark, 2005; Mote, 2003; Mote et al., 2005; Regonda et al., 2005; Serreze et al., 2000; Stewart et al., 2005). This is particularly germane at lower and mid-elevations where over the last 45 years previously snow-dominated regions have shifted to rain-domination without observed changes in total precipitation (Nayak et al., 2010). The

* Correspondence to: Michele L. Reba, Agricultural Research Service, Northwest Watershed Research Center, Boise, ID 83712, USA.

E-mail: michele.reba@ars.usda.gov implication of these studies is that the hydroclimatology of western mountain regions is unstable and changing, and that combinations of temperature and precipitation may occur that are outside of the historical record. Under these conditions, it is inappropriate to apply statistical models that are calibrated on historic relationships in an effort to forecast future hydrological conditions. The next generation of management models should be based on the physics of the processes involved and require little or no calibration.

Simulations should accurately represent snowcover development and ablation under a full range of climate conditions. Snow conditions where turbulent fluxes dominate melt as a result of the anticipated increase in mid-winter rain events and hence rain-on-snow events (Marks et al., 1998; Marks et al., 2001b). To evaluate the sensitivity of the seasonal snowcover to variable climate conditions, we will simulate the snowcover development and ablation over a range of recent and historical meteorology.

In this study, 25 years (1984-2008) of carefully processed forcing data were utilized to simulate the accumulation and ablation of the seasonal snowcover. The site is in a semi-arid western mountain environment. The data were collected within Reynolds Creek Experimental Watershed (RCEW), a US Department of Agriculture, 


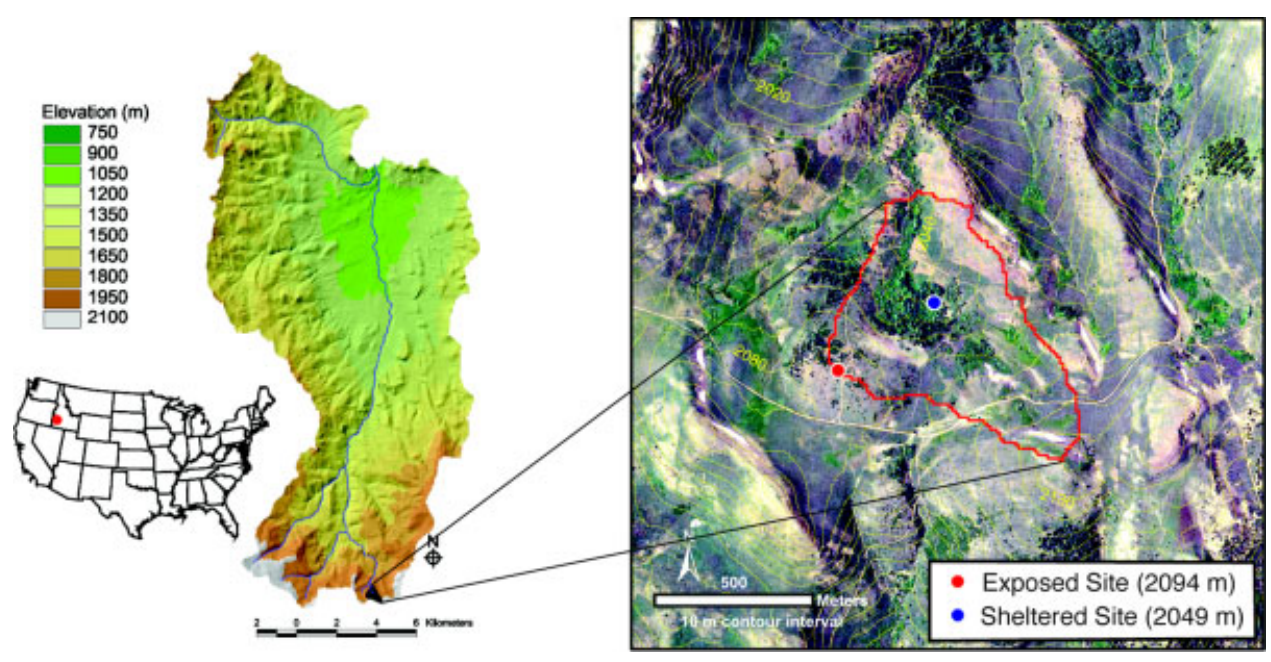

Figure 1. Study site reference of Reynolds Creek Experimental Watershed with inset of Reynolds Mountain East

Agricultural Research Service watershed (Flerchinger et al., 2007; Marks et al., 2001a; Marks et al., 2007; Robins et al., 1965). Given the variability measured over the 25 years, the conditions ranged from very wet and cool (VWC) to very dry and warm (VDW). This study will answer the following research questions: How well does the model simulate the seasonal snowcover over the range of climate variability measured over the last 25 years? How do these climate conditions influence the timing and magnitude of melt water input and stream discharge?

\section{METHODS}

\section{Study site}

This study took place in Reynolds Mountain East (RME), a sub-basin of the RCEW (Flerchinger et al., 2007; Marks et al., 2001a; Marks et al., 2007; Robins et al., 1965). RCEW is located $\sim 80 \mathrm{~km}$ southwest of Boise, ID in the Owyhee Mountains and was established in 1959 by congress to address issues related to water supply, seasonal snow, soil freezing, water quality, and rangeland hydrology (Slaughter et al., 2001). The RME sub-basin is a $0.4 \mathrm{~km}^{2}$ snow-dominated, headwater catchment (Figure 1). The elevation ranges from 2028 to 2137 masl. RME is characterized by patchy vegetation with $\sim 34 \%$ in fir and aspen, with sagebrush dominating the remaining portion of the catchment. Basin average precipitation for the snow season (1 November-15 May) over the last 25 years (1984-2008) was $688 \mathrm{~mm}$, with $\sim 81 \%$ falling as snow. Total precipitation averaged over the catchment area for the entire WY was $849 \mathrm{~mm}$ with $70 \%$ falling as snow. A WY runs from 1 October of the previous year through 30 September of the given WY. The WY is used in the western USA because most precipitation falls during the winter and spring months of November through April.

There are two primary meteorological sites located within RME with long-term data records. A wind- and topographically sheltered site is located in an aspen stand at $2049 \mathrm{~m}$ and a wind-exposed site is located among sagebrush at $2094 \mathrm{~m}$. A carefully collected and processed meteorological data set for the 1984-2008 WYs was assembled from these two sites and was used to drive snowcover energy and mass balance model simulations. The data set is fully described in Reba et al. (in press) and includes measured hourly precipitation, wind speed and direction, air and soil temperature, relative humidity, incoming solar radiation and calculated dew point temperature, and simulated thermal radiation.

In addition to the meteorological data collected at the sheltered site, a snow pillow measured snow water equivalent (SWE) continuously for the entire 25-year period of record. The snow pillow site is located adjacent to the sheltered site and because of topographic and vegetative sheltering often over-represents SWE when compared to the basin average. Peak seasonal SWE ranged from $186 \mathrm{~mm}$ in WY 1992 to $1087 \mathrm{~mm}$ in WY 1984. Data from the snow pillow indicate that, over the 25-year record, establishment of the seasonal snowpack was initiated between 12 October and 23 November with complete meltout occurring between 1 April and 11 June. Thirty-five-year bi-weekly maximum, average and minimum SWE (mm) measured at the high elevation snow courses within RCEW is presented in Figure 2. On average, peak SWE occurs around 1 April.

\section{Model description}

Isnobal is an extensively tested and well-validated two-layer snowcover energy and mass balance model (Marks and Dozier, 1992). The model is available in both point (Snobal) and grid-based or spatial configuration (Isnobal) (Marks et al., 1999b). Isnobal was used for this study. The model solves the snowcover energy and mass balance in one dimension at each 10-m DEM grid cell and requires no calibration. The model simulates both the development and ablation of the snowcover. An explicit rather than an iterative energy balance solution and a relatively simple two-layer representation of the snowcover are employed to achieve computational 


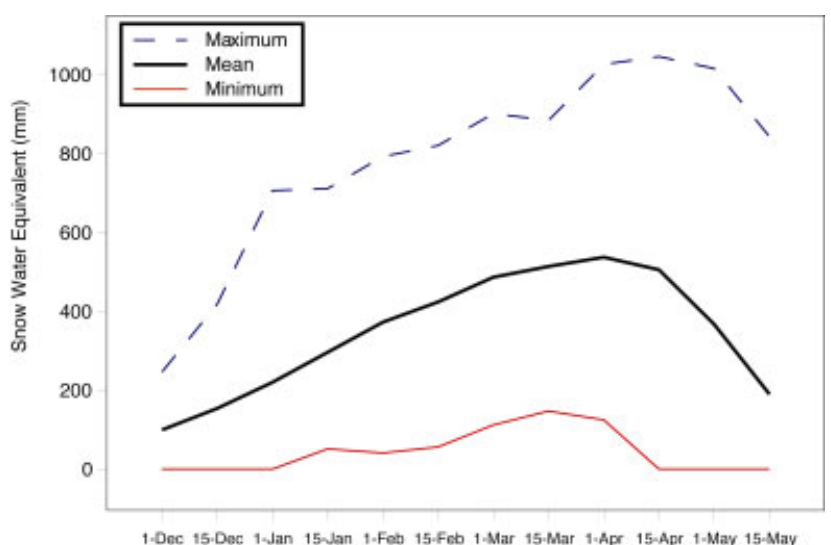

Figure 2. Thirty-five-year bi-weekly maximum, average, and minimum SWE (mm) measured at the high elevation snow courses within RCEW

efficiency. The model solves for the temperature and specific mass or depth of water equivalent per unit area for each snow layer. Melt is computed in either layer when the layer temperature reaches or exceeds the melting point $\left(0^{\circ} \mathrm{C}\right)$ and the accumulated energy exceeds the cold content. Melt drains from the base of the snowpack when the accumulated melt and liquid water content exceed a specified threshold of $0 \cdot 01$. The model readjusts the snowcover mass, thickness, thermal properties, and measurement heights for both the layers after each timestep. An hourly time-step was used for the simulations presented here.

Isnobal was run and the surfaces used to force the model were generated using the Image Processing Workbench, Version 2.1, software toolkit (Marks et al., 1999a). Two measurement sites, described above, were used to distribute measured meteorological data across the study area. Air temperatures were lapsed between the two measurement sites and distributed across the DEM grid. Measured relative humidity at the exposed site was assumed constant over the catchment and was converted to vapour pressure and dew point temperature using the distributed air temperature. Near-surface soil temperatures were assumed to be spatially constant. Precipitation at both sites was corrected for wind-induced undercatch as described by Hanson (2001). Solar radiation was generated from theoretical exothermic atmospheric radiation and corrected for atmospheric and cloud cover using measured values and methods described in Marks and Dozier (1992). Canopy effects were incorporated based on work from Link and Marks (1999a). Snow albedo was adjusted for aging and effective grain size (Marks et al., 1998; Marshall and Warren, 1987) and corrected for vegetation litter and organic debris (Hardy et al., 2004; Link and Marks, 1999a). Atmospheric thermal radiation was calculated over the DEM grid using methods described by Marks and Dozier (1979) then modified for cloud and vegetation cover, using measured solar depletion and a geographic information system (GIS)-derived canopy closure index (Link and Marks, 1999a,b; Marks and Dozier, 1992; Marks et al., 1992; Susong et al., 1999).
The model has accurately simulated the accumulation, melt and mass over small, medium (Marks et al., 1999b), and large catchments (Garen and Marks, 2005). The model is very robust and has been successfully applied and validated across a wide range of site and climate conditions (Link and Marks, 1999a,b; Marks et al., 1998; Marks and Winstral, 2001). While the primary validation for these efforts has been mass or SWE, detailed evaluations of radiation at the snow surface (Bewley et al., 2007; Essery et al., 2008; Hardy et al., 2004; Sicart et al., 2004), wind fields and snow deposition (Marks et al., 2002; Winstral and Marks, 2002), energy and mass exchange between the snow and the soil (Seyfried and Grant, 2007; Seyfried et al., 2009) and the mass and energy exchange between the snow and atmosphere (Marks et al., 2008) have also been conducted.

\section{RESULTS AND DISCUSSION}

\section{Meteorological categories}

To generalize the meteorological conditions during the snow season for the 25 WYs presented, each was categorized by both the precipitation and temperature condition. The snow season for each WY was defined as beginning on 1 November of the previous year and ended on 15 May of the given WY. The WYs were first sorted by the total basin average precipitation during the snow season. The driest and wettest snow seasons were classified as very dry and very wet. The very dry snow seasons ranged in total precipitation from 337 to $512 \mathrm{~mm}$, while the very wet snow seasons ranged from 886 to $1027 \mathrm{~mm}$. The remaining snow seasons were separated into dry and wet conditions. The range of total precipitation for a dry snow season was 553 to $669 \mathrm{~mm}$ and for wet was 696 to $859 \mathrm{~mm}$. The during storm temperature was determined to be warm or cool based on the proportion of total precipitation that was rain. The average snow season percent rain over the 25 years was $19 \%$. Snow seasons with greater than or equal to $19 \%$ rain were considered warm and less than $19 \%$ were considered cool. This scheme yielded eight classes with 2-5 WYs in each class (Table I).

Mean values for several parameters were generated for each of the eight classes. These parameters include

Table I. Category, abbreviation of category, and years within each category

\begin{tabular}{llc}
\hline Category & Abbreviations & \multicolumn{1}{c}{ Years } \\
\hline Very wet and cool & VWC & 1984,1986 \\
Very wet and warm & VWW & $1996,1997,2006$ \\
Wet and cool & WC & $1989,1999,2002$, \\
& & 2004,2008 \\
Wet and warm & WW & $1993,1995,1998$ \\
Dry and cool & DC & 1985,2000 \\
Dry and warm & DW & $2003,2005,2007$ \\
Very dry and cool & VDC & $1987,1994,2991$ \\
Very dry and warm & VDW & $1988,1990,1991$, \\
& & 1992 \\
\hline
\end{tabular}


Table II. WY statistics from simulated SWE and measured SWE at the snow pillow site and simulated SWI compared to discharge at the outlet, including category for each WY

\begin{tabular}{|c|c|c|c|c|c|c|c|c|c|}
\hline \multirow[t]{2}{*}{ Year } & \multirow[t]{2}{*}{ Category } & \multicolumn{4}{|c|}{ SWE } & \multicolumn{4}{|c|}{ SWI } \\
\hline & & NS & RMSD & MBD & RMBD & NS & RMSD & MBD & RMBD \\
\hline 1984 & VWC & $0 \cdot 97$ & 64 & 18 & $0 \cdot 04$ & 0.99 & 33 & -14 & -0.03 \\
\hline 1985 & DC & $0 \cdot 96$ & 38 & 24 & $0 \cdot 10$ & -0.53 & 191 & 172 & $0 \cdot 72$ \\
\hline 1986 & VWC & $0 \cdot 9$ & 84 & 54 & $0 \cdot 18$ & 0.92 & 67 & -37 & -0.09 \\
\hline 1987 & VDC & $0 \cdot 89$ & 36 & 24 & $0 \cdot 24$ & -5.95 & 158 & 142 & $1 \cdot 20$ \\
\hline 1988 & VDW & $0 \cdot 98$ & 17 & 1 & $0 \cdot 01$ & -3.06 & 140 & 131 & 0.99 \\
\hline 1989 & WC & 0.93 & 72 & 51 & $0 \cdot 17$ & 0.92 & 60 & 46 & $0 \cdot 12$ \\
\hline 1990 & VDW & 0.96 & 32 & -8 & -0.07 & $-1 \cdot 19$ & 194 & 177 & 0.96 \\
\hline 1991 & VDW & 0.77 & 53 & 39 & 0.33 & -1.71 & 173 & 146 & $1 \cdot 25$ \\
\hline 1992 & VDW & $0 \cdot 95$ & 14 & 1 & $0 \cdot 01$ & $-10 \cdot 01$ & 124 & 109 & 1.77 \\
\hline 1993 & WW & $0 \cdot 85$ & 87 & 60 & $0 \cdot 24$ & 0.73 & 144 & 137 & 0.40 \\
\hline 1994 & VDC & $0 \cdot 96$ & 24 & 6 & 0.05 & -5.06 & 176 & 145 & 1.77 \\
\hline 1995 & WW & $0 \cdot 74$ & 97 & 60 & $0 \cdot 22$ & $0 \cdot 61$ & 141 & 135 & 0.49 \\
\hline 1996 & VWW & 0.95 & 52 & 21 & $0 \cdot 09$ & $0 \cdot 98$ & 30 & 16 & 0.04 \\
\hline 1997 & VWW & 0.97 & 43 & 13 & 0.03 & 0.95 & 62 & -51 & $-0 \cdot 13$ \\
\hline 1998 & WW & $0 \cdot 89$ & 69 & 36 & $0 \cdot 18$ & $0 \cdot 85$ & 111 & 98 & 0.33 \\
\hline 1999 & WC & $0 \cdot 83$ & 109 & 69 & $0 \cdot 23$ & $0 \cdot 38$ & 156 & 116 & 0.44 \\
\hline 2000 & DC & $0 \cdot 92$ & 49 & 29 & $0 \cdot 19$ & $-2 \cdot 56$ & 237 & 214 & $1 \cdot 14$ \\
\hline 2001 & VDC & $0 \cdot 84$ & 53 & 27 & $0 \cdot 19$ & $-3 \cdot 90$ & 184 & 166 & 1.00 \\
\hline 2002 & WC & $0 \cdot 86$ & 95 & 63 & $0 \cdot 22$ & $-0 \cdot 36$ & 198 & 163 & 0.68 \\
\hline 2003 & DW & $0 \cdot 81$ & 51 & 28 & $0 \cdot 22$ & 0.73 & 54 & 42 & $0 \cdot 22$ \\
\hline 2004 & WC & $0 \cdot 92$ & 62 & 43 & $0 \cdot 20$ & -0.51 & 222 & 194 & 0.83 \\
\hline 2005 & DW & $0 \cdot 83$ & 51 & 33 & $0 \cdot 22$ & -0.39 & 166 & 145 & 0.59 \\
\hline 2006 & VWW & $0 \cdot 96$ & 53 & 26 & $0 \cdot 10$ & 0.98 & 34 & 26 & 0.06 \\
\hline 2007 & DW & $0 \cdot 91$ & 35 & 20 & $0 \cdot 17$ & -0.73 & 111 & 103 & 0.77 \\
\hline 2008 & WC & $0 \cdot 97$ & 45 & 4 & 0.02 & -0.74 & 247 & 214 & 0.90 \\
\hline
\end{tabular}

NS, Nash-Sutcliffe efficiency; RMSD, root mean square difference; MBD, mean bias difference; and RMBD, relative mean bias difference.

simulated values of accumulated SWE, surface water input (SWI), and sublimation and measured discharge. SWI is the amount of liquid water delivered to the soil surface from melting snow or from rain that passes through the snowcover or falls directly on the soil.

\section{Model performance}

Model performance was determined by comparing hourly simulated values of SWE and SWI to measured SWE and discharge, respectively. SWE is an important metric used for tracking snow season progress and seasonal water supply potential. Simulations of daily SWE from the snow pillow grid cell were compared to measured values of SWE at the snow pillow validation site. The SWI statistics were used in addition to the point measurement of SWE to test a more basin-wide integrated measure of model performance. Although SWI is not the sole determinant, it is tightly coupled to discharge (Marks et al., 2002). This relationship is most apparent after fall and early winter SWI satisfies soil and groundwater recharge. To reduce the uncertainty in the early winter season, the cumulative simulated basin average SWI was compared to cumulative measured stream discharge for the period from peak SWE to the end of the snow season.

Statistical analysis, including Nash-Sutcliffe (NS) model efficiency (Nash and Sutcliffe, 1970), root mean square difference (RMSD), mean bias difference (MBD), and relative mean bias difference (RMBD) were calculated for both SWE and SWI (see (Green and Stephenson,
1986) for details, (Link and Marks, 1999b) for application). NS model efficiency is a test of how well the model captures the variability in the measured values. NS values nearest to 1.0 illustrate that the simulated values have accounted for the variation in measured values. RMSD illustrates the absolute difference between the measured and simulated values and is a good measure of precision. MBD shows the bias between measured and simulated values and RMBD, the relative bias or MBD divided by the mean of the measured values.

Over the 25 WYs simulated, the model showed good agreement with measured values of SWE (Table II). The average NS over the 25 years simulated at the snow pillow was 0.90. NS model efficiencies for the snow pillow ranged from 0.74 to 0.98 , with $15 \mathrm{WYs}$ yielding values $>0.9,8>0.8$ and $2 \geq 0.74$ when comparing the snow pillow and simulated SWE. The average RMSD was $55 \mathrm{~mm}$ and ranged from 14 to $109 \mathrm{~mm}$. The magnitude of the residual is small in comparison to the magnitude and accuracy of the measurement. The average MBD was $30 \mathrm{~mm}$ and ranged from $<1$-to $69 \mathrm{~mm}$ with one negative value of $8 \mathrm{~mm}$. The MBD results suggest that although the bias is small, the model consistently overpredicts SWE. The average RMBD provides a context for the bias calculation and was $14 \%$ and ranged from 1 to $33 \%$. Averaging SWE statistics for the eight categories described above, yielded similar results. Warm and cool conditions yielded NS values of 0.89 and 0.91 , respectively, and RMSD values of 50 and $61 \mathrm{~mm}$, respectively. 
These values illustrate that the influence of temperature (warm or cool) does not impact model precision. The model captures variability characterized by mid-winter rains and rain-on-snow conditions equally as well as conditions that are characterized by mid-winter snow.

The statistics generated for SWI were mixed, although given the year-to-year variability of the period studied, these results were not unexpected (Table II). The statistics were independent of temperature condition and related heavily to the precipitation condition. Model statistics for SWI showed a high degree of simulation accuracy for very wet conditions, regardless of temperature. Average NS values for SWI of 0.96 and ranged from 0.92 to 0.99 . Two of the years categorized as wet yielded NS values for SWI of 0.85 in WY 1998 and 0.92 in WY 1989. However, the average NS values for SWI for wet years was $0 \cdot 25$. The average NS value for SWI for the dry and very dry conditions were -0.70 and -4.41 , respectively. RMSD values during very wet and wet conditions were smaller than during very dry and dry conditions. RMSD for very wet conditions ranged from 30 to $60 \mathrm{~mm}$ and was, on average, $6 \%$ of the discharge on 1 July. Bias was positive (greater simulated SWI than measured streamflow) in 22 of the 25 years studied, with small negative bias in 1984, 1986, and 1997. This was not unexpected due to large SWI before peak SWE during these years.

When cumulative discharge was a larger percentage of the cumulative SWI on 1 July, the model performed better. Again, these conditions were more common during very wet and wet conditions. These results can be attributed to the fraction of the SWI that goes to satisfy soil water storage. During dry years, this fraction is much larger than wet years and hence, less water is available for discharge. Also, during drier years, sublimation accounts for a larger percentage of water that is lost from the snowcover (Marks et al., 2002). These findings do not suggest that the model is inaccurately simulating SWI, but rather highlights the complexities of converting SWI to streamflow within the catchment.

\section{Basin average analysis}

Redistribution of snow from wind-exposed to protected locations accounts for vast differences in snow accumulation across the catchment. Spatial variability in melt energy dynamics and partitioning account for further differences in snow accumulation (Winstral and Marks, 2002). Spatially, the basin average allows for integration of conditions across the entire catchment. To generalize the $25 \mathrm{WYs}$ simulated and account for spatial variability in accumulation and ablation over the period of record, hourly basin average values are used. These hourly values were averaged for the years within each meteorological category and presented. In an effort to focus on the snow season, the analysis period begins on 1 October of the previous WY and ends on 1 July of the given WY.

Precipitation. The form and timing of precipitation influences the accumulation and ablation of the seasonal

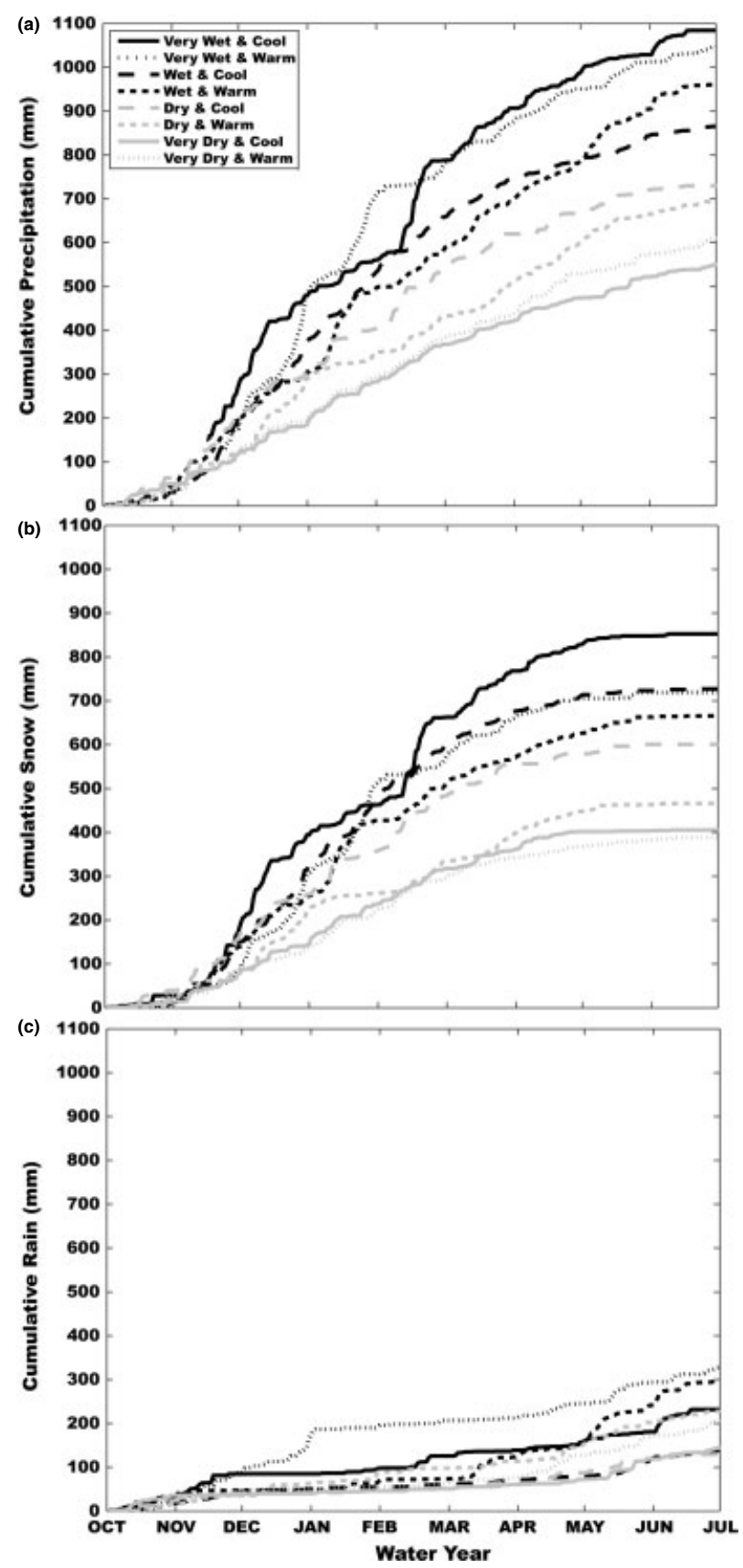

Figure 3. Measured mean cumulative precipitation (mm), total snow $(\mathrm{mm})$, and total rain $(\mathrm{mm})$ for each category from 1 October to 1 July

snowcover. Figure 3 shows the cumulative amount of total precipitation, snow, and rain from 1 October to 1 July for the eight categories. The total precipitation and percentage of precipitation that fell as rain are shown in Table III. As discussed previously, the total precipitation was used to determine the categories and these precipitation classes separate into distinct groups of dry and wet in Figure 3a. Figure 3b shows five [VWC, very wet and warm (VWW), wet and cool (WC), wet and warm (WW), and dry and cool (DC)] of the eight categories together with more snow and three [very dry and cool (VDC), VDW, and dry and warm (DW)] with less snow. Evidence of rain in all warm conditions occurred early in the winter for all precipitation conditions and increased 
Table III. Category, 1 July cumulative mean measured precipitation $(\mathrm{mm})$, percentage of the mean measured precipitation that fell as rain, peak simulated SWE (mm), date of peak simulated SWE, date of simulated meltout, 1 July cumulative simulated SWI (mm), date of $50 \%$ simulated SWI, 1 July cumulative mean measured discharge $(\mathrm{mm})$, date of $50 \%$ mean measured discharge, cumulative sublimation and condensation on 1 July $(\mathrm{mm})$, absolute value of simulated sublimation/cumulative measured discharge at meltout, and absolute value of simulated sublimation/peak simulated SWE

\begin{tabular}{lcccc}
\hline Category & $\begin{array}{c}\text { 1 July cumulative mean } \\
\text { measured precipitation } \\
(\mathrm{mm})\end{array}$ & $\begin{array}{c}\text { \% of mean measured } \\
\text { precipitation as rain }\end{array}$ & $\begin{array}{c}\text { Peak simulated SWE } \\
(\mathrm{mm})\end{array}$ & $\begin{array}{c}\text { Date of peak simulated } \\
\text { SWE }\end{array}$ \\
\hline VWC & 1085 & 21 & 706 & 13 April \\
VWW & 1047 & 31 & 491 & 5 April \\
WC & 866 & 16 & 611 & 3 April \\
WW & 962 & 31 & 467 & 8 March \\
DC & 730 & 18 & 503 & 30 March \\
DW & 694 & 33 & 239 & 4 April \\
VDC & 550 & 26 & 302 & 18 March \\
VDW & 611 & 34 & 248 & 12 March
\end{tabular}

\begin{tabular}{lcccc}
\hline Category & $\begin{array}{c}\text { Date of simulated } \\
\text { meltout }\end{array}$ & $\begin{array}{c}\text { 1 July cumulative simulated } \\
\text { SWI (mm) }\end{array}$ & $\begin{array}{c}\text { Date of 50\% simulated } \\
\text { SWI }\end{array}$ & $\begin{array}{c}\text { 1 July cumulative mean } \\
\text { measured discharge (mm) }\end{array}$ \\
\hline VWC & 8 July & 1070 & 23 May & 949 \\
VWW & 13 June & 1040 & 26 April & 798 \\
WC & 27 June & 846 & 9 May & 571 \\
WW & 18 June & 968 & 6 May & 724 \\
DC & 11 June & 717 & 23 April & 420 \\
DW & 4 June & 677 & 24 April & 365 \\
VDC & 25 May & 523 & 25 April & 236 \\
VDW & 10 June & 567 & 18 April & 257 \\
\end{tabular}

\begin{tabular}{lcccc}
\hline Category & $\begin{array}{c}\text { Date of 50\% mean } \\
\text { measured discharge }\end{array}$ & $\begin{array}{c}\text { 1 July cumulative sublimation/ } \\
\text { condensation (mm) }\end{array}$ & $\begin{array}{c}\text { Absolute value of simulated } \\
\text { sublimation/ cumulative measured } \\
\text { discharge at meltout (\%) }\end{array}$ & $\begin{array}{c}\text { Absolute value of } \\
\text { simulated sublimation/peak } \\
\text { simulated SWE (\%) }\end{array}$ \\
\hline VWC & 21 May & -12 & 1 & 2 \\
VWW & 6 May & -16 & 2 & 3 \\
WC & 17 May & -20 & 4 & 3 \\
WW & 13 May & 7 & 1 & 1 \\
DC & 4 May & -14 & 3 & 3 \\
DW & 1 May & -17 & 5 & 7 \\
VDC & 30 April & -26 & 12 & 9 \\
VDW & 2 May & -24 & 10 & 10 \\
\hline
\end{tabular}

markedly during spring months (Figure 3c). Cool precipitation conditions showed little rain until mid-April, except for a few rain events in the very wet precipitation condition. Generally, the total amount of rain varied little between categories. Rain for drier categories makes up a much larger proportion of total precipitation than wetter categories.

Snow water equivalent. The magnitudes and temporal distribution of the SWE over the accumulation and ablation season was strongly influenced by the meteorological condition (Figure 4a). As the category criteria were based on total precipitation this was not surprising. VWC yielded the most SWE of the eight conditions, while VDW yielded the least (Table III). Snowcover was established for all categories by early- to mid-November. By mid-December, VWC had $\sim 300 \mathrm{~mm}$ of SWE, while VWW was roughly a third of this amount and did not begin to double this amount of SWE until January. VWC retained snow longer than the other categories with snow lasting into early July (Table III). All dry categories were snow free by late-May.

Generally, cool conditions yielded more SWE given the same precipitation condition (Figure 4a). Warm conditions flattened out the accumulation trace during the mid-winter period of mid-January to late-April, while cool conditions continue to gain mass through this period. This was most pronounced in the WC and WW categories. The accumulation for both are similar until midJanuary when SWE for WW flattened out, while SWE for WC continued to gain mass. For DW, rain events on an established snowcover flatten the mass accumulation in early December. This condition continues through early April, while DC gains substantial SWE during the same period. Flattening of the VWW also occurs compared to VWC beginning in early February. There is little difference between VDC and VDW although VDC is slightly higher.

The timing of peak SWE was different in warm and cool categories, with warm peaking before cool 
(a)
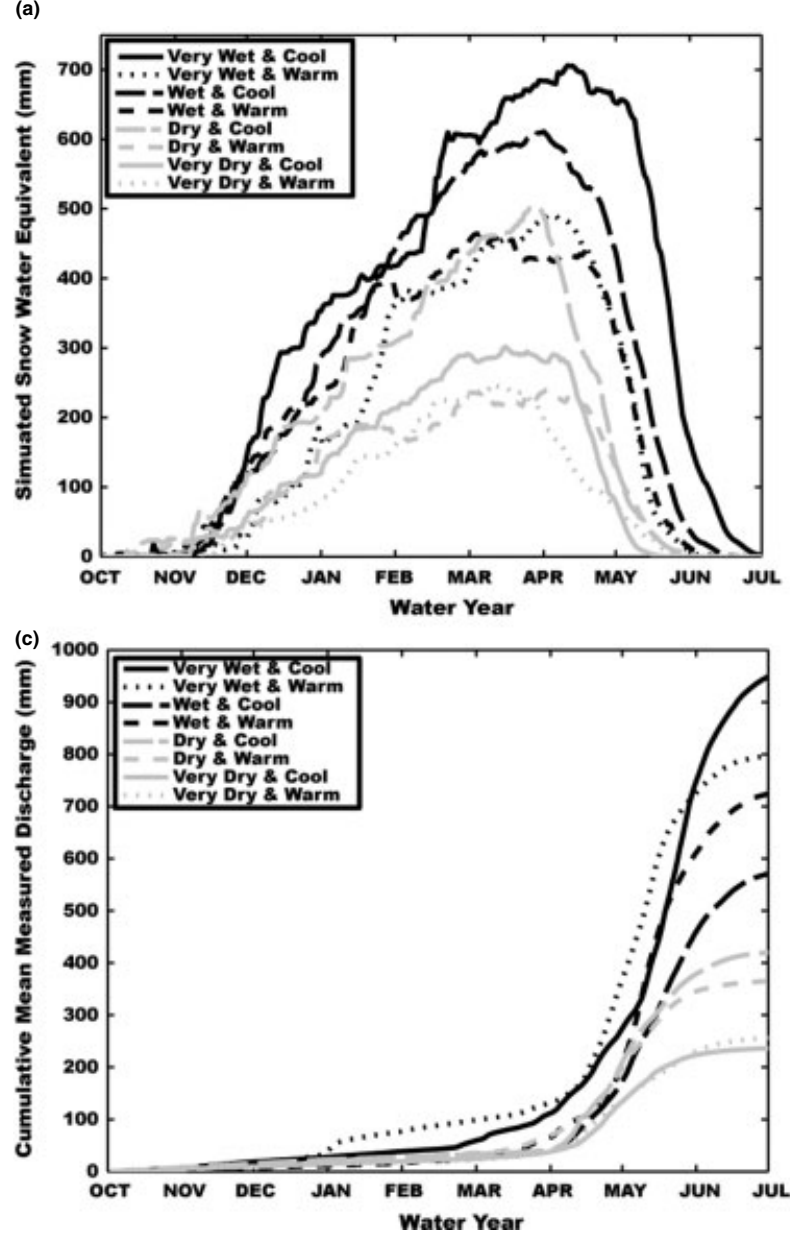

(b)

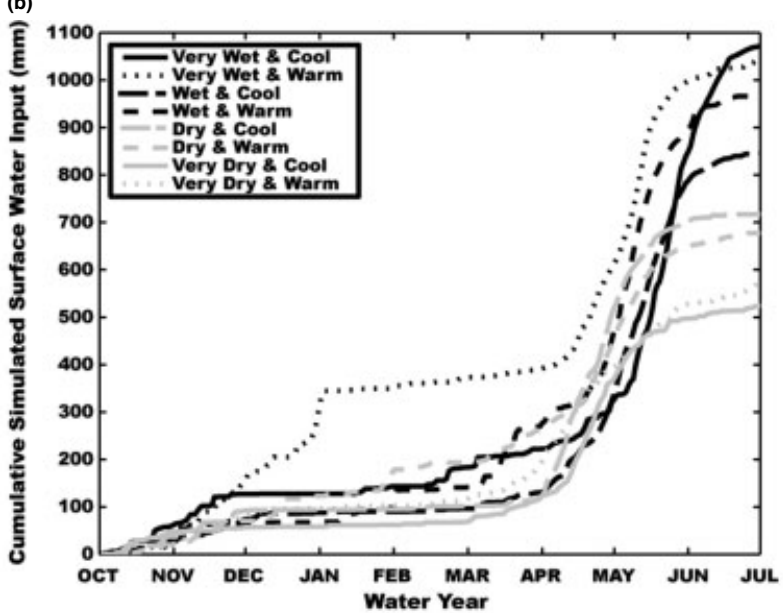

(d)

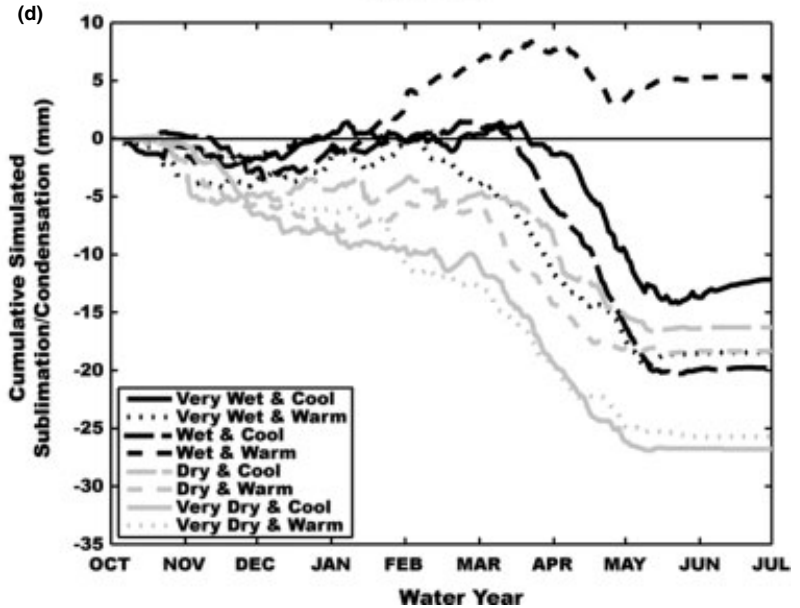

Figure 4. (a) Mean cumulative simulated SWE (mm) for each category from 1 October to 1 July. (b) Mean cumulative simulated SWI (mm) for each category from 1 October to 1 July. (c) Mean cumulative simulated stream discharge (mm) for each category from 1 October to 1 July. (d) Mean cumulative simulated sublimation and condensation $(\mathrm{mm})$ for each category from 1 October to 1 July

(Table III). The largest difference in peak values was observed in the wet category where WW peaked 26 days before WC. VWW peaked 11 days before VWC and VDW peaked 6 days before VDC. DW exhibited a double peak, with the peak values separated by $\sim 2 \mathrm{~mm}$. The first DW peak occurred 21 days before DC peak and the second DW peak occurred 5 days after the DC peak.

Surface water input. SWI for each of the categories was dominated by the temperature condition and secondarily by precipitation (Figure $4 b$ ). Similar to SWE, wet conditions and dry conditions are distinctly separated. Evidence of an early initiation of SWI was apparent in all warm conditions, especially in VWW due to a large amount of fall precipitation that was a mix of rain and snow. The warm conditions increased cumulative SWI during mid-winter, while the cool conditions delay SWI until early March for VWC and early April for the WC, DC, and VDC. The majority of increases in SWI are triggered by smaller mid-winter rain events with the exception of the large late December rain event in VWW.

The largest total SWI occurred in the very wet conditions with $\sim 30 \mathrm{~mm}$ less for VWW compared to VWC (Table III). Large spring rain events for WW yielded $968 \mathrm{~mm}$, while the WC yielded $846 \mathrm{~mm}$ of SWI. The dry and very dry conditions were similar regardless of temperature. Both DC and DW yielded $\sim 700 \mathrm{~mm}$ and the VDC and VDW yielded $\sim 545 \mathrm{~mm}$ of SWI.

The timing of the delivery of SWI is important hydrologically. The date when half of the cumulative SWI has been delivered was used as a metric to understand the differences in timing between categories. Given very dry or very wet levels of precipitation, warm conditions generated half of the total SWI earlier than would have been the case for cool conditions (Table III). VDW and VWW passed $50 \%$ of the SWI 7 and 27 days earlier when compared to VDC and VWC, respectively. WW and DW were within 1-3 days of WC and DC.

Discharge. Measured discharge was averaged for the year within each of the meteorological categories and presented in Figure 4c. Given similar precipitation, temperature influenced the timing of discharge between October and July (Figure 4c). All warm conditions generate discharge earlier than cool conditions for the same precipitation category. The date when $50 \%$ cumulative stream discharge leaves the catchment was used as a metric to understand the differences in timing between categories (Table III). However, except for the very wet conditions all categories show similar timing in reaching the $50 \%$ 
discharge level with only $2-4$ days between the warm and cool conditions, with the warm condition passing $50 \%$ of the discharge before the cool. The exception was VWW, which passed 50\% of the discharge 15 days before VWC.

Differences in timing of discharge under warm conditions compared to cool are also attributed to winter rain events occurring on an established snowcover (Figure 4c), although in general the response is not as rapid as with SWE and SWI. For all conditions but the very dry, increases in cumulative discharge before early April are linked to mid-winter rain. The large event in early January in VWW clearly influences discharge early compared to VWC. VWC also illustrates the influence of mid-winter rain in mid-February. However, for the other categories, the need to satisfy soil water storage results in a delay in the increases in discharge until early March.

During the melt season, the contribution from snowmelt dominated the discharge and cool conditions yielded larger cumulative totals than the warm conditions (Figure $4 \mathrm{c}$ and Table III). The one exception was for WC and WW where large rain events occurred that increased the cumulative discharge totals for WW and were $153 \mathrm{~mm}$ (27\%) larger than WC.

Sublimation/Condensation. Sublimation is the loss of mass due to the change in phase from solid to vapour and is reported here as a negative value. Condensation is the addition of mass due to a phase change from vapour to solid and is reported here as a positive value. The sign convention is in relation to the snowcover. Sublimation is a loss of mass from the snowcover to the atmosphere and negative, while condensation is a gain of mass to the snowcover and positive. The meteorological condition has less influence in simulated sublimation than it did for SWE, SWI, and stream discharge (Figure 4d). This could be due to the reduction in the signal when sublimation and condensation events were averaged over $2-5$ years. The VDC and VDW had the most cumulative sublimation and WW was dominated by condensation.

Until December, energy associated with phase change was minimal and mostly negative for all categories. From December to February, there was a mix of condensation and sublimation with condensation coincident with rain events for all conditions. After February, VDW exhibited only sublimation until the snow season ended, while all other categories exhibited a mix of condensation and sublimation until approximately March. By mid- to late-March, all categories except WW showed consistent sublimation until the end of the snow season. WW was dominated by condensation until early April. These events occurred during WY 1993 and WY 1995 when warm condensing conditions were established over the snowcover. Although these events occurred in other years, the signal was not as strong and was not seen in the mean values during most categories.

Condensation during rain events adds energy to the snowcover and accelerates melt (Marks et al., 1998). The influence of rain on the sublimation characterization is shown clearly in Figure 4d. Condensation events are temporally linked to rain events for all conditions. This is particularly illustrated in WW as condensation occurred throughout winter and early spring.

The cumulative sublimation/condensation for each category on 1 July is shown in Table III. VDC and VDW yielded the largest cumulative sublimation, between -24 and $-26 \mathrm{~mm}$, because of the limited condensation. All other categories, except the condensation-driven WW, yielded between -12 and $-20 \mathrm{~mm}$ of cumulative sublimation. However, the cumulative sublimation does not consider the relative importance in the context of the availability of SWE for each category.

To place sublimation loss in the context of the amount of water available within the catchment, the absolute value of sublimation was calculated as a percentage of the cumulative discharge when the snow completely ablated and as a percentage of the peak SWE (Table III). For all categories but very dry, sublimation as a percentage of cumulative discharge ranged from 1 to $5 \%$. VDC was $10 \%$ and VDW was $12 \%$. Sublimation as a percentage of peak SWE yielded similar results with VDC, VDW, and DW ranging between 7 and 10\% of peak SWE. For all other categories, the sublimation was less than $3 \%$ of peak SWE. These values are consistent with measured values in the area (Reba et al., in review). The sublimation loss during the VDC, DCW, and DW constituted a hydrologically important percentage of water available to the system. In general, sublimation loss during drier conditions reduces water availability and is hydrologically more important.

\section{SUMMARY AND CONCLUSIONS}

The energy balance approach to seasonal snowcover modelling using Isnobal (Marks et al., 1999b; Marks and Dozier, 1992) was shown to be accurate under the varied meteorological conditions that occurred during the 25 WYs simulated. Given this variability, the average model efficiency was 0.90 when comparing simulated and measured SWE at a measurement site. As interest in seasonal snowcover response under changing climate conditions increases, the use of a physically based energy balance model has several advantages. First, an energy balance model does not require calibration to the tested conditions. Second, with projected climate warming rain-on-snow events are expected to increase. These events are typically associated with large latent and sensible heat flux energy and are difficult to capture without accounting for the physics associated with the processes. It was also found that the model accuracy was essentially equal for warm conditions, characterized by winter rain, and snow resulting in rain-on-snow, and cool conditions, characterized by winter snow and spring rain. On the basis of these findings, the energy balance model, Isnobal, is appropriate for use in studying the influence a perturbed climate may have on the seasonal snowcover. Furthermore, the model could be used to test 
the sensitivity of snowcover development under modified climate conditions.

The form and timing of precipitation influenced accumulation and melt markedly. The 25 snow seasons were grouped into eight categories based first on total basin average precipitation and second on winter storm temperature. The categories and associated WYs are described in Table I. Warm winters, characterized by mid- and early winter rain, resulted in earlier SWI and stream discharge when compared to cool winters. Cool conditions delayed the generation of SWI and stream discharge. Warmer conditions produced less SWE, shortened the melt season and would be expected to extend the summer drought. Drier conditions were prone to more sublimation losses, which constituted a larger percentage of the peak SWE and measured discharge than wetter conditions.

These findings are based on carefully measured and processed data over a 25-year period that includes a full range of climatic variability. The study years include both the wettest and driest WYs recorded for the region. We feel the simulation results are representative of the interior mountain west in North America. The exception to this is the results from the WW category, which included somewhat anomalous condensation conditions.

Predictions of more rain and less snow as climate warms across the west are particularly germane to the results presented here. More rain, especially winter rain, will influence the availability of SWI to the catchment and the timing and delivery of water for stream discharge and related water supplies. In the short term, these changes will influence the amount and distribution of soil moisture and hence water available to the ecosystem and agriculture. Furthermore, forecasting based on historical snow deposition will be ineffective and modifications to the forecasting approach should be considered. In the long term, the influence of these changes on water availability will influence patterns of vegetation and agricultural practices.

\section{REFERENCES}

Bewley D, Pomeroy J, Essery R. 2007. Solar radiation transfer through a sub-arctic shrub canopy. Arctic, Antarctic and Alpine Research 39(3): 365-374.

Cayan D, Kammerdiener S, Dettinger M, Caprio J, Peterson D. 2001. Changes in the onset of spring in the Western United States. Bulletin of the American Meteorological Society 82(3): 399-415.

Essery R, Bunting P, Hardy J, Link T, Marks D, Melloh R, Pomeroy J, Rowlands A, Rutter N. 2008. Radiative transfer modeling of a coniferous canopy characterized by airborne remote sensing. Journal of Hydrometeorology 9(2): 228-241.

Flerchinger G, Marks D, Seyfried M, Pierson FP, Nayak A, Hardegree SP, Winstral AH, Clark PE. 2007. 45 Years of climate and hydrologic research conducted at Reynolds Creek Experimental Watershed. In Environmental and Water Resources: Milestones in Engineering History, ASCE Environmental and Water Resources Institute (EWRI) National History \& Heritage Committee, Rogers JR (eds); American Society of Civil Engineers: Reston, VA, USA; 135-143.

Garen D, Marks D. 2005. Spatially distributed energy balance snowmelt modelling in a mountainous river basin: estimation of meteorological inputs and verification of model results. Journal of Hydrology 315 : $126-153$.

Green IRA, Stephenson D. 1986. Criteria for comparison of single event models. Hydrological Sciences Journal 31(3): 395-411.
Hanson C. 2001. Long-term precipitation database, Reynolds Creek Experimental Watershed, Idaho, USA. Water Resources Research 37(11): 2831-2834.

Hardy JP, Melloh R, Koenig G, Marks D, Winstral A, Pomeroy J, Link T. 2004. Solar radiation transmission through conifer canopies. Journal of Agricultural and Forest Meteorology 126: 257-270.

IPCC. 2007. Contributions of Working Group I to the Fourth Assessment Report of the Intergovernmental Panel on Climate Change. Fourth Assessment Report of the Intergovernmental Panel on Climate Change. Climate Change 2007: The Physical Science Basis, Solomon S, Qin D, Manning M, Chen Z, Marquis M, Averyt K, Tignor M, Miller H (eds). Cambridge University Press: Cambridge, UK/New York, USA; 989 pp.

Link T, Marks D. 1999a. Distributed simulation of snowcover mass- and energy balance in a boreal forest. Hydrological Processes 13(13-14): 2439-2452.

Link T, Marks D. 1999b. Point simulation of seasonal snow cover dynamics beneath boreal forest canopies. Journal of Geophysical Research 104(D22): 27,841-27,857.

Marks D, Domingo J, Frew J. 1999a. Software Tools for Hydro-climatic Modeling and Analysis: Image Processing Workbench, ARS-USGS Version 2. NWRC-99-1, Northwest Watershed Research Center, USDA Agricultural Research Service: Boise, ID, USA.

Marks D, Domingo J, Susong D, Link TE, Garen D. 1999b. A spatially distributed energy balance snowmelt model for application in mountain basins. Hydrological Processes 13: 1935-1959.

Marks D, Dozier J. 1979. A clear-sky longwave radiation model for remote alpine areas. Archiv fur Meteorologie, Geophysik und Bioklimatologie, Series B 27(23): 159-187.

Marks D, Dozier J. 1992. Climate and energy exchange at the snow surface in the alpine region of the Sierra Nevada: 2 snow cover energy balanceWater Resources Research 28(11): 3043-3054.

Marks D, Dozier J, Davis RE. 1992. Climate and energy exchange at the snow surface in the Alpine region of the Sierra Nevada: 1 meteorological measurements and monitoring. Water Resources Research 28(11): 3029-3042.

Marks D, Kimball J, Tingey D, Link T. 1998. The sensitivity of snowmelt processes to climate conditions and forest cover during rainon-snow: a study of the 1996 Pacific Northwest flood. Hydrological Processes 12(10-11): 1569-1587.

Marks D, Cooley KR, Robertson DC, Winstral A. 2001a. Long-term snow database, Reynolds Creek Experimental Watershed, Idaho, USA. Water Resources Research 37(11): 2835-2838.

Marks D, Link T, Winstral A, Garen D. 2001b. Simulating snowmelt processes during rain-on-snow over a semi-arid mountain basin. Annals of Glaciology 32: 195-202.

Marks D, Reba ML, Pomeroy J, Link T, Winstral A, Flerchinger G, Elder K. 2008. Comparing simulated and measured sensible and latent heat fluxes over snow under a pine canopy. Journal of Hydrometeorology 9: 1506-1522. DOI:10.1175/2008JHM874.1.

Marks D, Seyfried M, Flerchinger G, Winstral A. 2007. Research data collection at the Reynolds Creek Experimental Watershed. Journal of Service Climatology 1(1): 1-18.

Marks D, Winstral A. 2001. Comparison of snow deposition, the snowcover energy balance, and snowmelt at two sites in a semi-arid mountain basin. Journal of Hydrometeorology 2(3): 213-227.

Marks D, Winstral A, Seyfried M. 2002. Simulation of terrain and forest shelter effects on patterns of snow deposition, snowmelt and runoff over a semi-arid mountain catchment. Hydrological Processes 16(18): 3605-3626.

Marshall SE, Warren SG. 1987. In Large Scale Effects of Seasonal Snow Cover, IAHS-AIHS Publication 166. Goodison RGBBE, Dozier J (eds). International Association of Hydrological Sciences: Wallingford, UK; 43-50.

McCabe GJ, Clark MP. 2005. Trends and variability in snowmelt runoff in the western United States. Journal of Hydrometeorology 6: 476-482.

Mote P. 2003. Twentieth-century fluctuations and trends in temperature, precipitation, and mountain snowpack in the Georgia Basin-Puget Sound region. Canadian Water Resources Journal 28(4): 567-585.

Mote P, Hamlet AF, Clark MP, Lettenmaier DP. 2005. Declining mountain snowpack in western North America. Bull. Amer. Meteor. Soc. 86: 39-49.

Nash JE, Sutcliffe JV. 1970. River flow forecasting through concpetual models, Part I-A discussion of principals. Journal of Hydrology 10: 282-290.

Nayak A, Marks D, Chandler DG, Seyfried M. 2010. Long-term snow, climate, and streamflow trends at the Reynolds Creek Experimental Watershed, Owyhee Mountains, Idaho, United States. Water Resources Research 46: W06519. 
Reba M, Marks D, Seyfried M, Winstral A, Kumar M, Flerchinger G. 2011. A 25-year data set for hydrologic modeling in a snow-dominated mountain catchment. Water Resources Research. DOI: 2010WR010030.

Reba M, Pomeroy J, Marks D, Link T. 2011. Estimating surface sublimation losses from snowpacks in a mountain catchment using eddy covariance and turbulent transfer calculations. Hydrological Processes (in review).

Regonda S, Rajgopalan B, Clark M, Pitlick J. 2005. Seasonal cycle shifts in hydroclimatology over the Western United States. Journal of Climate 18: $372-384$.

Robins JS, Kelly LL, Hamon WR. 1965. Reynolds Creek in southwest Idaho: an outdoor hydrologic laboratory. Water Resources Research 1(3): 407-413.

Serreze MC, Walsh JE, Chapin FSI, Osterkamp TE, Dyurgerov M, Romanovsky V, Oechel W, Morison J, Zhang T, Barry RG. 2000. Observational evidence of recent change in the Northern high-latitude environment. Climatic Change 46: 159-207.

Seyfried MS, Grant LE. 2007. Temperature effects on soil dielectric properties measured at $50 \mathrm{MHz}$. Vadose Zone Journal 6: 759-765.

Seyfried MS, Grant LE, Winstral A, Marks D, McNamara JP. 2009. Simulated soil water storage effects on streamflow generation in a mountainous snowmelt environment, Idaho, USA. Hydrological Processes 23: 858-873.

Sicart J, Pomeroy J, Essery R, Hardy J, Link T, Marks D. 2004. A sensitivity study of daytime net radiation during snowmelt to forest canopy and atmospheric conditions. Journal of Hydrometeorology 5: $774-784$.

Slaughter CW, Marks D, Flerchinger GN, VanVactor SS, Burgess M 2001. Thirty-five years of research data collection at the Reynolds Creek Experimental Watershed, Idaho, United States. Water Resources Research 37(11): 2819-2823.

Stewart I, Cayan D, Dettinger M. 2005. Changes towards earlier streamflow timing across Western North America. Journal of Climate 18: $1136-1155$.

Susong D, Marks D, Garen D. 1999. Methods of developing time-series climate surfaces to drive topographically distributed energy-and waterbalance models. Hydrological Processes 46: 2003-2021.

Trenberth KE, Jones PD, Ambenje P, Bojariu R, Easterling D, Klein Tank A, Parker D, Rahimzadeh F, Renwick J, Rusticucci M, Soden B, Zhai P. 2007. Observations: surface and atmospheric climate change. In Climate Change 2007: The Physical Science Basis, Contributions of Working Group 1 to the Fourth Assessment Report of the Intergovernmental Panel on Climate Change, Solomon S, Qin D, Manning M, Chen Z, Marquis M, Averyt K, Tignor M, Miller H (eds). Cambridge University Press: Cambridge, UK and New York, NY, USA; 235-336.

Winstral A, Marks D. 2002. Simulating wind fields and snow redistribution using terrain-based parameters to model snow accumulation and melt over a semi-arid mountain catchment. Hydrological Processes 16(18): 3585-3603. 